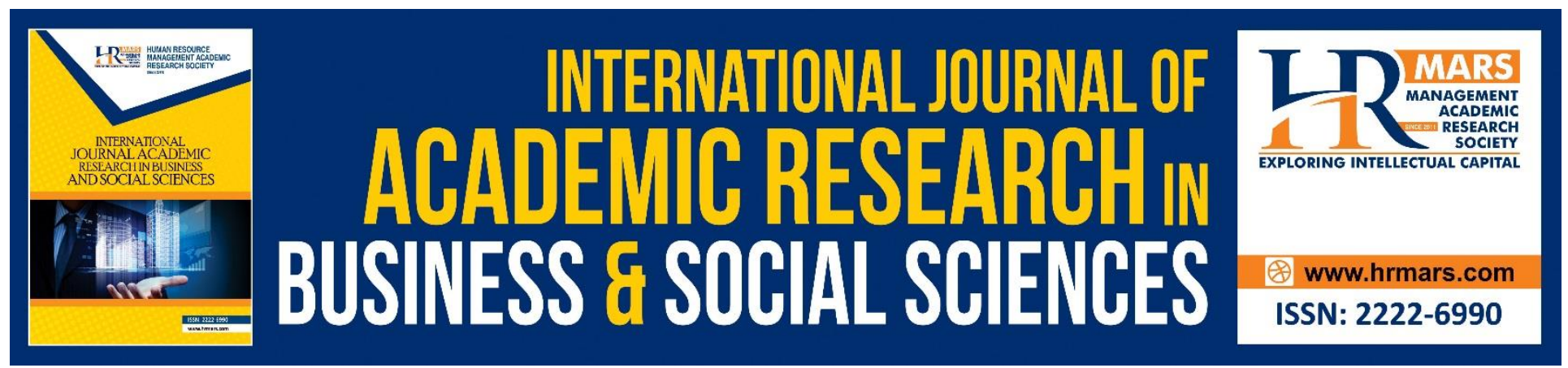

\title{
Interest and Aesthetic towards Quatrains
}

\section{Normaliza Abd Rahim, Nur Maisarah Roslan and Nur Widad Roslan}

To Link this Article: http://dx.doi.org/10.6007/IJARBSS/v10-i10/7731

DOI:10.6007/IJARBSS/v10-i10/7731

Received: 01 August 2020, Revised: 27 August 2020, Accepted: 20 September 2020

Published Online: 24 October 2020

In-Text Citation: (Abd Rahim, Roslan, and Roslan, 2020)

To Cite this Article: Abd Rahim, N., Roslan, N. M., and Roslan, N. W. (2020). Interest and Aesthetic towards Quatrains. International Journal of Academic Research in Business and Social Sciences. 10(10), 467-477.

Copyright: @ 2020 The Author(s)

Published by Human Resource Management Academic Research Society (www.hrmars.com)

This article is published under the Creative Commons Attribution (CC BY 4.0) license. Anyone may reproduce, distribute, translate and create derivative works of this article (for both commercial and non-commercial purposes), subject to full attribution to the original publication and authors. The full terms of this license may be seen at: http://creativecommons.org/licences/by/4.0/legalcode

Vol. 10, No. 10, 2020, Pg. 467 - 477

http://hrmars.com/index.php/pages/detail/IJARBSS

JOURNAL HOMEPAGE

Full Terms \& Conditions of access and use can be found at http://hrmars.com/index.php/pages/detail/publication-ethics 


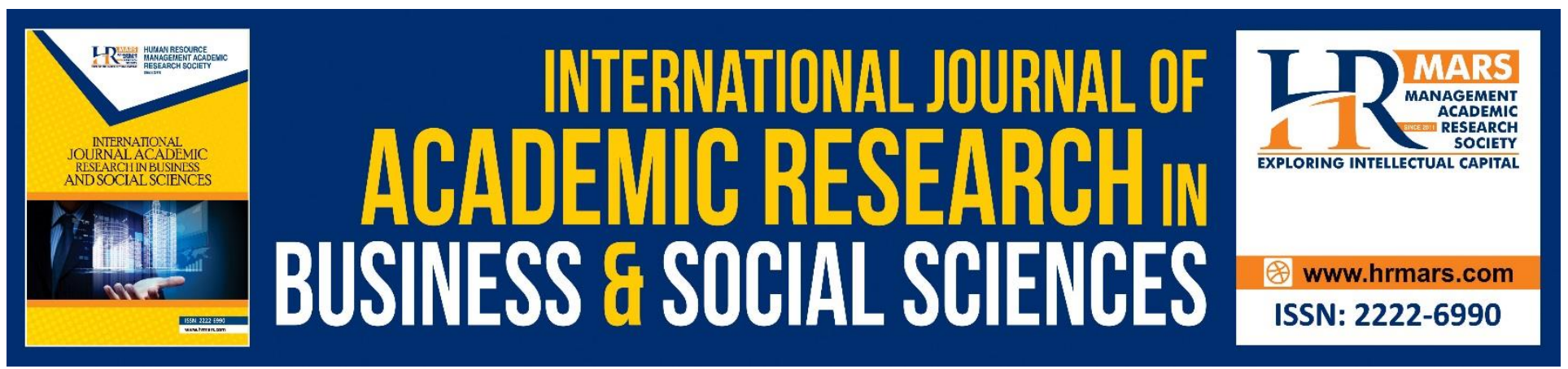

\title{
Interest and Aesthetic towards Quatrains
}

\section{${ }^{1}$ Normaliza Abd Rahim, ${ }^{2}$ Nur Maisarah Roslan and ${ }^{3}$ Nur Widad Roslan}

${ }^{1}$ Department of Malay Language, Faculty of Modern Languages and Communication, Universiti

Putra Malaysia, UPM 43400 Serdang, Selangor, Malaysia, ${ }^{2}$ Faculty of Modern Languages and

Communication, Universiti Putra Malaysia, UPM 43400 Serdang, Selangor, Malaysia, ${ }^{3}$ Faculty of Modern Languages and Communication, Universiti Putra Malaysia, UPM 43400 Serdang, Selangor, Malaysia

Email: ${ }^{1}$ nliza@upm.edu.my, ${ }^{2}$ maisaroslan@gmail.com, ${ }^{3}$ widad.roslan@gmail.com

\begin{abstract}
Malay quatrain was introduced to students who studied Malay language and literature in the universities from all over the world. It is one of the Malay literature genres. Therefore, this study aims to introduce Malay quatrain among Korean learners. The objectives of the study are to investigate and discuss Korean students' perceptions and aesthetic values toward Malay quatrains. The subjects of the study involved a class of 18 university students in one of the universities in South Korea. All of the subjects are majoring in Malay-Indonesian Interpretation and Translation, thus, they have been exposed to Malay quatrains in the previous semester. The subjects were interviewed informally on their perceptions toward Malay quatrains. The subjects were divided into groups of threes and fours in order for them to discuss the Malay quatrain. The results of the study found that the subjects showed great interest and understanding toward the Malay quatrain and moreover, they had learned the aesthetic values in the Malay quatrains. The study has given implication toward educators and students who studied Malay language and literature in appreciating the Malay quatrain. It is hoped that future research will investigate in depth on the aesthetic values of two stanzas of Malay quatrains.
\end{abstract}

Keywords: Perception, Malay Quatrains, Interest, Beauty, Harmony.

\section{Introduction}

Malay quatrain is one of Malay literature genres and was introduced to students who studied Malay language and literature in the universities from all over the world. Malay quatrain continues to be used among the people in Malaysia no matter what the occasion is, whether it be a formal event or a part of everyday life. Malay quatrain consists of lines with meanings, and these meanings are sometimes based on the aesthetic values in order to inform and provide awareness of Malay quatrain to the people (Saluddin, 2007; Arshad, 1967). Nowadays, Malay quatrain is not favored by the younger generation and therefore, the Ministry of Education in Malaysia has taken steps in order to 
INTERNATIONAL JOURNAL OF ACADEMIC RESEARCH IN BUSINESS AND SOCIAL SCIENCES Vol. 10, No. 10, 2020, E-ISSN: 2222-6990 @ 2020 HRMARS

inculcate and enhance the use of Malay quatrain in Malay language lessons. The syllabus for primary and secondary schools has been revised for the purpose of giving awareness to youngsters and to utilize the Malay quatrain where it is necessary. The steps taken by the government

has given young people the time to think and understand the legacy of the Malays through the Malay quatrain. Thus, it is clearly seen that the Ministry of Education has done a splendid job in disseminating the Malay quatrain through school books and even in formal ceremonies conducted by the school in order to expose students to the quatrain. A well written Malay quatrain consists of aesthetic values. The values have been disseminated through Malay quatrains to both readers and listeners.

According to Rahim (2020c), numerous ways of research were done in order to find the answer problem solving and the results are shared among the viewers who would want improvement in life. Countless methods and theories are used so that the study can be done well and efficiently. This study relates to the study by Rahim, Roslan, Roslan and Roslan (2020) where others interpretations towards learning as well as the climate change has literally affected their learning style. Rahim (2019a) agreed whereby different learning style will produce a healthier learning environment. Rahim (2019b) study is similar where climate change has made learners to be able to learn better in the new setting. Changes in learning gives an impact on aesthetic learning among students in the classroom. Mansor and Rahim (2019) mentioned that the use of social media in learning is seen as an appealing platform to improve student learning. Rahim (2020b) agreed where the use of digital technology is being used all over the world nowadays. Therefore, digital technology gives a big impact on students' learning in the classroom. For instant, in digital technology learning, integration of values and culture in Malay folklore animation were done. Rahim and Harun (2016); Rahim et al. (2016) agreed with that where Malay folklore songs has given encouraging effects on students' insights and Malay folklore tend to catch the interest of all type of students and it gives an impression towards their knowledge of Malay folklore.

Theories on the aesthetic values have been discussed among researchers. The term 'aesthetic' is derived from the Greek word 'aesthesis,' which means sensory perception. The terms gained philosophy in the eighteenth-century after British Enlightenment theorists, such as Hutcheson (1725) and Hume (1757), developed influential theories on sense and beauty. Here, the sense of taste was introduced, which allegedly enable us to make judgments of beauty and ugliness. Another theorist, Kant (1790), postulates that the concept of aesthetic judgments is nonconceptual and is focused entirely on pleasure or displeasure. Kant (1790) states and considers aesthetic judgments as 'subjective,' as in either pleasure or displeasure. Kant (1790) claims that the judgments of the beautiful involve a claim to universality, thus, the judgment that something is beautiful involves the claim that others should agree with this judgment. Another researcher, Hume (1757), emphasizes that humans do not treat all judgments of taste as equally valid. He adds that the ability of some works of art to pass the 'test of time' seems to provide reason for thinking that aesthetic value is not simply relative to individuals or cultures. Thus, radical subjectivism or anything with regards to relativism about aesthetic value seems implausible. On the other hand, while many philosophers reject relativism altogether, some believe that a degree of relativism is a characteristic of the domain of aesthetic value (Hume, 1757; Goldman, 2001; Eaton, 2001). 
INTERNATIONAL JOURNAL OF ACADEMIC RESEARCH IN BUSINESS AND SOCIAL SCIENCES Vol. 10, No. 10, 2020, E-ISSN: 2222-6990 @ 2020 HRMARS

Based on Kant's (1790) views on aesthetic values, researchers from the twentieth century had shown great interests toward judgments. Apart from this fact, aesthetic attitude theorists, such as Bullough (1912); Stolnitz (1960), defended the view on the characteristically non-practical mode of contemplating an object either with disinterestedness or with distance. Here, it can be said that such view allows one to recognize the aesthetic features of objects. Dickie (1964) criticizes on aesthetic attitude, both on the grounds of psychological implausibility and because it excessively dissociates the aesthetic from the cognitive and moral value. Danto (1981); Walton (1970); Gaut (2007) had presented the current development involving the expansion of the category of the aesthetic. They postulate that aesthetic value is thus not restricted to the formal features of artworks, but increasingly, it tends to be thought of as dependent on, or interacting with, a variety of other aspects; most notably, contextual, cognitive, and moral factors. On the other hand, other researchers state that aesthetic value contributes to our wellbeing and a good life (Eaton, 1989; Brady, 2006; Goldie, 2008; Irvin, 2010; Musa et al., 2012), which contributes to the dissemination of values among communities.

A research on Malay quatrain was conducted by Rahim et al. (2011), focusing on Malay quatrain in the form of a software. The objectives of this study were to identify the values in Malay quatrain and to discuss the interactions among the group members during a discussion. The samples of the study were a class of primary school student from a region in Malaysia. The subjects were given a software consisting of Malay quatrains activities. The subjects were divided in pairs and then, they were briefed about the program. After trying the activities in the program, the subjects discussed with other group members (Franklin, 2005) about Malay quatrains. The instruments used in this study were observation and interview. The findings of this study revealed that the subjects were interested in Malay quatrain and they managed to understand the quatrains by looking at the answers given to them. The subjects also showed high confidence when dealing with the activities in the program (Rahim \& Harun, 2011). By looking at the content of the program, which is interesting and suitable for all students, this study implicates not only educators, students, and researchers, but also software providers as well (Rahim et al., 2011).

According to Isenin et al. (2010); Francois-Rene (1988), Malay quatrain is the thought of the community. The quatrain was able to change members of the community to become better people and hence, awareness about the self will be discovered. The research by Isenin et al. (2010) explores the history of quatrain, definition, types, and functions of the quatrain toward the culture and philosophy. Isenin et al. (2010) in Rahim et al. (2011) state that the study concentrates on traditional quatrain toward the Malay community in Malaysia. Moreover, the research states that the traditional quatrain gives advice and moral values in a meaningful way in order for a person to gain awareness and harmony in their lives. Therefore, the use of Malay quatrain has been widely used among the younger and older generations. These generations have been using simple Malay quatrain from schools to more complex Malay quatrain at formal events.

A research conducted by Abdullah (2009) stated that Malay quatrain was widely used in Malay weddings. The quatrains were used during the engagement ceremony as well as during the wedding. The Malays still used the quatrain in order to express their appreciation and thanks to the guests at the wedding. Abdullah (2009) researched on a number of famous Malay quatrains that have been 
INTERNATIONAL JOURNAL OF ACADEMIC RESEARCH IN BUSINESS AND SOCIAL SCIENCES Vol. 10, No. 10, 2020, E-ISSN: 2222-6990 @ 2020 HRMARS

used in Malay wedding and found out that although the quatrains were used occasionally, the quatrains still maintained its uniqueness and messages underlying in it. Everyone in the ceremony would feel satisfied after listening to the quatrain and this has given a positive impact toward the listeners. Musa (2008) postulates that using traditional poetry will make the listener happy and content and also make the listener realize the meaning of the poetry. Musa (2008) and Musa et al. (2012) listed 26 kindness of the heart among the Malays, and these lists will be disseminated through Malay literature genres, similar to Malay quatrains.

The objectives of this study are:

- To investigate Korean students' perceptions and aesthetic values toward Malay Quatrains.

- To discuss Korean students' perceptions and aesthetic values toward Malay Quatrains.

\section{Methodology}

The subjects of the study involved 18 male and female university students from one of the universities in South Korea. The subjects' major is Malay-Indonesian Interpretation and Translation. They were exposed to Malay quatrains in the previous semester. The subjects were interviewed informally on their perceptions toward Malay quatrains. They were also divided into groups of threes and fours in order for them to discuss the Malay quatrain. Extracts of their discussion were analyzed for the purpose of the study. The discussion was analyzed by using the discourse analysis theory by Rahim (2020). According to Rahim (2020), there are three elements in discourse analysis theory. The elements are content, context and assumption. However, this study will only focus on the third element in analyzing the data. According to Rahim (2020), assumption in discourse is considered as thing that are accepted as true or certain will happen, without proof. Assumption also means something that is considered true, even without evidence. Sometimes assumptions are made in the hope that things really happen.

\section{Results and Discussion}

\section{INTEREST and understanding of Malay quatrain}

The subjects involved in this study seemed to be interested in the Malay quatrain. They were amazed with the rhyme for each line and when they read it, the rhythmic sound made them happy and content. When they became interested in Malay quatrain, they tried to understand the meaning of each quatrain. They even discussed their ideas with their group members. They were enthusiastic with the discussion and tried to give their views and opinions on the meaning of the quatrain. The subjects' perceptions that showed interest and understanding were as follows.

I like the sound of each quatrain.

The first and second are connected and I love writing it.

I just found out that the third and fourth line consist of meanings for the quatrain.

I would use the Malay quatrain in my next presentation.

I like the idea of having Malay quatrain in my writing.

The subjects showed their interest in Malay quatrain as shown in the above perceptions. They seemed to enjoy Malay quatrain and thus, had given good comments about the quatrain. The subjects mentioned that in Korean literature, there were no quatrains so this was the first time that they actually experienced quatrains. They had shown interest toward the quatrain and as a matter of 
fact, they realized the rules of writing Malay quatrain. The above interactions were the subjects' suggestion

and feelings toward Malay quatrain. They were amazed with the new literature genre that they had learnt and they were happy to learn more about it. The subjects uttered words such as 'like,' 'love,' 'just found,' 'would use,' and 'like the idea,' which also meant that they were happy to learn more about Malay quatrain. On the other hand, the subjects even uttered words that were related to Malay quatrain. They expressed themselves with words and at the same time, they had a smile of their faces. They were happy to express their feelings about the quatrain since they knew that what they said was true. The quatrain allowed them to say things that they could not have directly uttered, hence, the quatrain was the best solution to solve such problem. The subjects uttered the following words in order to explain the quatrain:

Splendid

Marvelous

Sensitive

Happy

Nice words

Deep meaning

About nature

Appreciation

In the above, the words given by the subjects to describe Malay quatrain were all positive remarks toward the quatrain. The subjects were happy to mention it and they even provided examples when asked. The subjects showed great interest and understanding toward the quatrain. Moreover, the words expressed their opinions and views about the quatrain. This showed that Malay quatrain had made them change their perceptions to become positive because in the beginning, they mentioned that Malay quatrains were difficult to understand. Although the subjects were struggling with the meaning of the quatrain, after being taught on the meaning of each word, they were content with their study. With the statement by the subjects, it was clearly shown that Malay quatrain has helped them in the learning process. Subsequently, the subjects asked questions pertaining to Malay quatrains. They asked their group members for confirmation. For each quatrain, they were also unsure as to the meaning and it seemed that after the discussion with the group members, they understood the quatrain clearly. The subjects seemed to be able to accept views and opinions from the other group members and at the same time, their opinions were heard by the other members (Bouton and Garth, 1983). This way, they shared their knowledge and willingness to discuss in groups. The questions were answered by the group members, making the task more fun. The subjects asked questions as follows:

What does this line mean?

Does this mean that the mountain is lonely?

What happened to the boy in this line?

Do you think that the river resembles the boy?

What do you think of this meaning?

The questions above were discussed among the group members. They were happy to give their opinions. Each subject would give different answers but after a long discussion, they understood the 
INTERNATIONAL JOURNAL OF ACADEMIC RESEARCH IN BUSINESS AND SOCIAL SCIENCES Vol. 10, No. 10, 2020, E-ISSN: 2222-6990 @ 2020 HRMARS

reasons for such differences and they were happy to accept the answers (Cahn, 2006). A majority of the questions were based on the meaning and understanding of the quatrain. Also, the questions asked by the subjects seemed to seek for assurance from the group members. The questions regarding the 'mountain' and 'river,' as seen above, sought for assurance and the subjects seemed to suggest answers to the group members. This also showed interest and confidence among the subjects.

\section{AESTHETIC values in Malay quatrain}

Most Malay quatrains consist of aesthetic values. The values increase the subjects' willingness to read more since these values provide the subjects with happiness and satisfaction. The subjects seemed to be content with Malay quatrains that were given to them and they managed to understand the meaning of each. As a matter of fact, they managed to find the aesthetic values in the quatrains. Their perceptions about the aesthetic values were as follows:

This quatrain is about the beauty of nature.

The love toward others was stated in this quatrain.

The beauty of a human being is clearly stated here.

The sense of appreciation was explained in this quatrain.

This is harmony here in this quatrain.

In the above, subjects' perceptions implied that they understood the aesthetic values of the Malay quatrain. The subjects even mentioned the words that were related to aesthetic values, such as beauty, love, appreciation, and harmony. These values were a few among the lists of aesthetic values in Malay literature and they managed to list some of them. This showed that the subjects understood the meaning of the quatrain and furthermore, this showed that they had the confidence to give their ideas and views about the quatrain. The perceptions also showed that the subjects were proud to offer their opinions to the group members. Furthermore, the above perceptions also discussed the aesthetic values in Malay quatrains. The subjects were able to identify the aesthetic values and hence, understand the meaning implied. This showed that the subjects were open to learning new things and were content with the aesthetic values in the quatrains.

Moreover, the subjects also uttered words in order to provide the meaning of each quatrain. The subjects managed to discuss well among the group members and uttered the aesthetic values in the quatrains. Fortunately, the uttered words answered the questions related to the quatrain. Although they were sceptical with the words in the beginning, after seeing other group members smile and agree to the answers, they were happy and content. The subjects' uttered words related to the aesthetic value 'beauty' as follows:

Love

Nice

Appreciation

Harmony

Being good

Sincerity

Generosity 
The above words that were related to the aesthetic values showed that the subjects understood the meaning of each word. The subjects tried to relate the words with their everyday lives hence, they also tried to relate to the quatrain given to them. The subjects seemed to be content with the words suggested by the group members and they agreed to accept the answers. Before accepting the answers, they were seen discussing the words with the other group members (Carlsmith and Cooper, 2002) and referred to the quatrain again for assurance. The words discussed by the subjects consisted of aesthetic values, which made them aware of the meaning of the words. Thus, the subjects were content with the aesthetic values (Saito, 2007) discussed. On the other hand, the subjects seemed to question the aesthetic values pertaining to certain quatrains. The questions were based on their answers that were not similar to the group members. Although they had different answers, they managed to sort the problem as soon as discussion among the group members began. The subjects' questions were as follows:

Do you think sincerity is better than the one suggested?

I would rather have generosity for this quatrain, don't you think so?

This quatrain clearly has different meaning, what do you think?

What makes you say that this quatrain has the meaning that you suggested?

This was not clear, don't you think so?

The above questions clearly showed that the subjects were questioning the aesthetic values in the quatrain. The subjects seemed to be unsure in the beginning and therefore, asked questions to the other group members. The subjects participated in a discussion on the questions asked and after a long discussion, they managed to give the right answers. Even though the questions were asked among the group members, they seemed to accept the questions in a positive way since they mentioned that with the questions, they managed to look at the quatrain again with better understanding. It was oblivious that the subjects were questioning the aesthetic values in the Malay quatrain and the group members managed to give the answers through the discussion. This showed that the aesthetic values were well discussed among the subjects and with questions and answers, the subjects were able to understand better.

\section{Summary of Results}

To sum up the results for both the interest and understanding of the Malay quatrains as well as the aesthetic values (Saito, 2007) in the Malay quatrains, were discussed among the subjects. The subjects were enthusiastic in offering their opinions during the discussion. The subjects were also seen confident with the answers pertaining to the quatrain and moreover, they were happy and content in learning the Malay quatrains, which consist of aesthetic values. The results of this study is parallel to the results of the study by Rahim et al. (2011) where Malay quatrain would give them the chance to discuss in their groups confidently (Laister \& Kober, 2010). Simultaneously, the subjects understood the content, which consists of aesthetic values (Brady, 2006). This study also has the same results as the study by Rahim and Harun (2011) and King (2002), where small group discussions will boost up the subjects' confidence level as well as their positive perception toward Malay literature. Moreover, this study reveals the aesthetic values, which are similar to the research done by Musa (2008) and Musa et al. (2012) where the kindness of the heart was important in everyone's life thereby ensuring unity and harmony within the community. A study by Suraya Amiruddin et al. (2019) is parallel with this study where social stories are enhanced through communicative strategies 
INTERNATIONAL JOURNAL OF ACADEMIC RESEARCH IN BUSINESS AND SOCIAL SCIENCES Vol. 10, No. 10, 2020, E-ISSN: 2222-6990 @ 2020 HRMARS

as it provides chances for language users to use the strategies for the purpose of effective communication. This study is also similar to a study by Rahim et al. (2017) where interaction in language learning may cause confusion among language learners. This study is parallel with a study by Rahim (2020d) where discourse study needed in forming a meaningful content in speech, interaction, text and writing. Discourse studies can also have an impact in providing a better and stronger understanding among the language users.

\section{Conclusion}

The authors conclude that this study implicates educators of Malay literature and Malay language. This study also implicates other language educators in enhancing literature among students learning a second language. University students will receive the benefit of this study since they now know that through discussions, there will be good outcome. It is hoped that future research will concentrate on other Malay literature genres among Korean learners. Also, through teaching and learning Malay literature, media technology can be incorporated in the overall teaching and learning realms.

The study contributes to ministry of higher education and universities in designing and planning literature curriculum by including quatrain in teaching and learning. On the other hand, this study contributes to authors and writers of quatrain by giving new ideas and perception in order to increase the love towards literature. Students will also benefit by learning new things in literature where they will inculcate culture in quatrain.

\section{References}

Isenin, A., Sakari, Z., \& Jalil, S. A. (2010). Pantun Sebagai Manifestasi Minda Masyarakat. Bahasa, Pemikiran dan Integrasi. Prosiding Seminar Antarabangsa Psikolinguistik II, pp. 236-242.

Brady, E. (2006). Aesthetics in Practice: Valuing the Natural World. Environmental Values, 15, pp. $277-$ 291.

Brown, G., \& Yule, G. (1983). Discourse Analysis. Cambridge University Press: Cambridge.

Bouton, C., \& Russell, Y, G. (1983). Learning in Groups: New Directions in Teaching and Learning. San Francisco, CA: Jossey-Bass.

Bullough, E. (1912). 'Psychical Distance' as a Factor in Art and as an Aesthetic Principle. British Journal of Psychology, 5, pp. 87-117.

Cahn, D. (2006). Managing Conflict through Communication. (3rd Edition). Allyn and Bacon: USA.

Carlsmith, M., \& Cooper, J. (2002). A Persuasive Example of Collaborative Learning. Teaching of Psychology, 29(2), pp. 132-135.

Danto, A. (1981). The Transfiguration of the Commonplace. Cambridge, MA: Harvard University Press.

Dickie, G. (1964). The Myth of the Aesthetic Attitude. American Philosophical Quarterly, 1, pp. 56-65.

Eaton, M. (2002). Merit, Aesthetic and Ethical. Oxford: Oxford University Press.

Eaton, M. (1989). Aesthetics and the Good Life. Rutherford, NJ: Farleigh Dickinson University Press.

Francois-Rene, D. (1988). Alam pantun Melayu. Kuala Lumpur: Dewan Bahasa dan Pustaka.

Abdullah, F. (2009). Pantun Sebagai Perakam Norma: Penelitian Awal Terhadap Perkahwinan dan Keluarga Melayu. Jurnal Melayu, (4), pp. 43-57.

Franklin, K. (2005). Special Strategies for Small Language Groups: Part 1: Rethinking Stories. International Journal of Frontier Missions, 22 (1), pp. 6-12.

Gaut, B. (2007). Art, Emotion and Ethics. Oxford: Oxford University Press. 
INTERNATIONAL JOURNAL OF ACADEMIC RESEARCH IN BUSINESS AND SOCIAL SCIENCES

Vol. 10, No. 10, 2020, E-ISSN: 2222-6990 @ 2020 HRMARS

Goldie, P. (2008). Virtues of Art and Human Well-Being. Proceedings of the Aristotelian Society Supplement, 82, pp. 179-95.

Goldman, A. (2001). Aesthetic Value. Boulder, CO: Westview Press.

Musa, H. (2008). Hati Budi Melayu: Pengukuhan Menghadapi Cabaran Abad ke-21. Serdang: Penerbit Universiti Putra Malaysia.

Musa, H., Said, N. S., Rodi, R. C., \& Karim, S. S. A. (2012). Hati Budi Melayu: Kajian Keperibadian Sosial Melayu Ke Arah Penjanaan Melayu Gemilang. GEMA Online ${ }^{T M}$ Journal of Language Studies, 12(1), pp. 163-182.

Hume, D. (1985). Of the Standard of Taste. In E.F. Miller (Ed.) Essays, Moral, Political, Literary. Indianapolis, IN: Liberty Fund.

Hutcheson, F. (1725/2004). An Inquiry into the Origin of the Ideas of Beauty and Virtue. Edited by W. Leidhold, Indianapolis, IN: Liberty Fund.

Kant, I. (1790/2001). Critique of the Power of Judgement. Edited by Guyer, P., translated by Guyer, P. and Matthews, E., Cambridge: Cambridge University Press.

King, A. (2002). Structuring Peer Interaction to Promote High-level Cognitive Processing. Theory Into Practice, 41(1), pp. 33-39.

Laister \& Kober. (2010). Social Aspects of Collaborative Learning in Virtual Learning Environments. Retrieved 25 June 2012 from http://comma.doc.ic.ac.uk/inverse/papers/patras/19.htm

Saludin, M. R. (2007). Puisi Melayu Tradisional. Penang: Goal Intelligent Publishing.

Arshad, M. Y. (1967). Pantun. Kuala Lumpur: Dewan Bahasa dan Pustaka.

Mansor, N., \& Rahim, N. A. (2019). Eh! Media Sosial. Universiti Malaysia Terengganu: Penerbit Universiti Malaysia Terengganu.

Rahim, N. A. (2019). Kajian Wacana dan Strategi Komunikasi: Teori dan Aplikasi. Universiti Malaysia Terengganu: Penerbit Universiti Malaysia Terengganu.

Rahim, N. A. (2019). Multimedia dalam Bahasa. Universiti Putra Malaysia: Penerbit Universiti Putra Malaysia.

Rahim, N. A. (2020a). Kajian Wacana dan Penerimaan Teknologi. Serdang: Penerbit Universiti Putra Malaysia.

Rahim, N. A. (2020b). Perspektif Teknologi Digital. Serdang: Penerbit Universiti Putra Malaysia.

Rahim, N. A. (2020c). Spek[c]trum Penyelidikan. in. Normaliza Abd Rahim(Ed). Spek[c]trum Penyelidikan: Teori dan Aplikasi (pp. 1-6). Terengganu: Penerbit Universiti Malaysia Terengganu.

Rahim, N. A. (2020d). Kajian Wacana. In Normaliza Abd Rahim (Ed). Penyelidikan Wacana; Teori dan Aplikasi (pp. 1-7). Terengganu: Penerbit Universiti Malaysia Terengganu.

Rahim, N. A., \& Harun, N. I. (2011). Emotions among the Primary School Students: A Malay Drama Program (Software). Journal UPENA, 10, pp. 1-10.

Rahim, N. A., \& Roslan, S. N. A. (2009). The Art of Acting Students' Feelings and Emotions. The International Journal of the Humanities, 7 (8), pp. 1-12.

Rahim, N. A., \& Harun, N. I. (2016). Students' Perception towards Malay Folklore Songs. Springer Science and Business Media Singapore 2016 Regional Conference on Science, Technology and Social Sciences (RCSTSS 2014). DOI 10.1007/978-981-10-1458-1_59, 641-648.

Rahim, N. A., Halim, H. A., Mamat, R., \& Mansor, N. S. (2016). Malay Folklore Discourse among Korean Students. Jurnal Kemanusian, 25 (1), pp. 12-21. 
INTERNATIONAL JOURNAL OF ACADEMIC RESEARCH IN BUSINESS AND SOCIAL SCIENCES

Vol. 10, No. 10, 2020, E-ISSN: 2222-6990 @ 2020 HRMARS

Rahim, N. A., Halim, H. A., Mamat, R., Mansor, N. S., \& Roslan, S. N. A. (2017). Confusion in Interaction among Korean Learners. Journal of Business and Social Development, 5 (10), pp. 18-24.

Rahim, N. A., Pawi, A. A. A., \& Affendi, N. R. N. M. (2018). Integration of Values and Culture in Malay Folklore Animation. Pertanika J. Soc. Sci. \& Humanities, 26 (1), pp. $359-374$.

Rahim, N. A., Roslan, S. N. A., Roslan, N. M., \& Roslan, N. W. (2020). The Effects of Climate Change. In Normaliza Abd Rahim (Ed). Spek[c]trum Penyelidikan: Teori dan Aplikasi (pp. 189-196). Terengganu: Penerbit Universiti Malaysia Terengganu.

Saito, Y. (2007). Everyday Aesthetics. Oxford: Oxford University Press.

Stolnitz, J. (1960). Aesthetics and Philosophy of Art Criticism. A Critical Introduction. Boston, MA: Houghton Mifflin Co. Print.

Amiruddin, S., Rahim, N. A., Halim, H. A., \& Jalaludin, I. (2019). Social Stories to Enhance Communicative Strategies Among Autism Spectrum Disorder (ASD) Children. Jurnal Komunikasi: Malaysian Journal of Communication, 35(2) 2019: pp. 87-102.

Walton, K. (1970). Categories of Art. Philosophical Review, 79, pp. 334-367. 